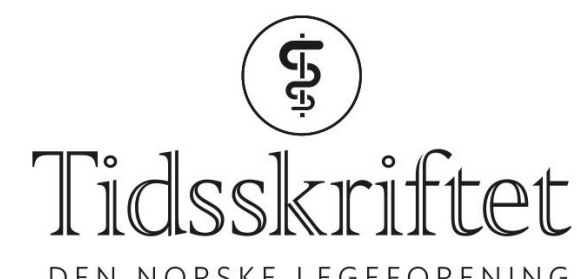

DEN NORSKE LEGEFORENING

\title{
Michael Matzen
}

MINNEORD

FRANK E. ÅBYHOLM

CHARLES FILIP

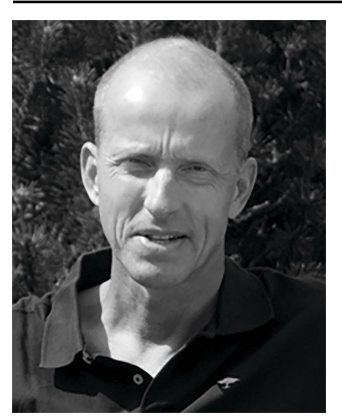

Den 24. september 2020 mottok vi den sørgelige melding at vår kjære kollega og venn Michael Matzen var gått bort.

Michael ble cand.odont. ved Århus Tandlægehøjskole i 1983, og cand.med. ved Århus Universitet i 1986. Han fikk sin plastikkirurgiske utdannelse ved Roskilde Amt sykehus og Odense sykehus i perioden 2001-04.

Michael Matzen kom til Rikshospitalet i 2004 og ble overlege ved avdelingen samme år. Med sin dobbelutdannelse som lege og tannlege ble Michael en verdifull ressurs i det multidisiplinære team som hadde ansvaret for behandling av barn med leppe-, kjeve- og ganespalte, og i 2006 ble han seksjonens leder. Hans arbeid var preget av faglig dyktighet og stor arbeidskapasitet, og han hadde en genuin interesse for sitt fag. Michael hadde en spesiell evne til å få kontakt med barna og deres foreldre, og det er mange som har meget å takke ham for. Michael Matzen var en stor ressurs for Rikshospitalet, og han nøt stor respekt fra alle personalgrupper i spalteteamet.

Dessverre ble Michael rammet av en alvorlig sykdom i 2014 og reiste tilbake til Danmark, hvor han døde bare 64 år gammel.

Vi vil huske Michael som en god og lojal venn og dyktig medarbeider. Han vil bli dypt savnet.

Våre tanker og dype medfølelse går til hans hustru Helle og deres to barn. Vi lyser fred over hans minne. 
(ㅇ) Tidsskrift for Den norske legeforening 2020. Lastet ned fra tidsskriftet.no 